\title{
Sentencing Circles, Clashing Worldviews, and the Case of Christopher Pauchay
}

\author{
Toby Susan Goldbach, Cornell University
}

\begin{abstract}
The case of Christopher Pauchay demonstrates some of the differences between predominant Euro-Canadian and First Nations approaches to dispute resolution. The principles of sentencing circles sometimes overlap with the principles of restorative justice and suggest their potential incorporation into the criminal justice system. The use of alternative processes that share some common values is not enough to overcome to chasm between Euro-Western and Aboriginal justice. Where underlying worldviews differ, those who can choose between competing values amidst limited possibilities will likely choose the values that reflect the conventional system. A comparison of Euro-Western and Aboriginal approaches to crime and punishment clarifies why Pauchay's sentencing circle was unsuccessful as an alternative option. Advocates of alternative methods must consider more than the implementation of a process when adapting selective cultural methods to the overarching system. Without further evaluation, alternative dispute resolution (ADR) itself becomes a mechanism of recolonization.
\end{abstract}

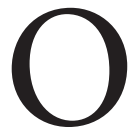

n January 28, 2007, Christopher Pauchay drank heavily after a heated argument with his wife. Sometime after midnight, he began to worry that something was wrong with one of his daughters. Hoping to find help, Pauchay took his two girls out in the freezing winter air, dressed only their T-shirts. Both girls were found dead in the following days. Pauchay pled guilty to criminal negligence causing death and requested that a sentencing circle be 


\section{Tony Susan Goldbach}

held to determine the appropriate sentence. ${ }^{1}$

Sensitive to the role that addiction might have played in the tragedy, and noting that Pauchay expressed a desire to make changes in his life, Provincial Court Justice Morgan was favourable towards the request for a sentencing circle. The request, however, was controversial. The Crown objected based on the circumstances and severity of the crime, and argued that the appropriate sentence was a term of imprisonment for two-anda half to five years, which would preclude the court from legally imposing conditions on the offender. There was also public condemnation of the request. A news report referred to sentencing circles as a "charitable approach" which bore "an uncomfortable similarity to a group hug for both victims and

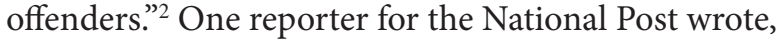

$[\mathrm{H}]$ ealing the guilty party is not supposed to be the primary purpose of a criminal sentencing anyway. There's a reason we still call it 'criminal justice.' And that points to one of the inherent problems with aboriginal sentencing circles. Given full control of Pauchay's fate, the people of the Yellow Quill band could turn the world's horror and disgust into grudging respect by saying, 'Your punishment is to go stand outside in a snowbank until you're a Popsicle. The community has spoken.'

Following Pauchay's request, a sentencing circle was held and recommendations for sentencing were made to the judge. The Pauchay case, the use of the sentencing circle and the judge's ultimate disposition serve as the basis for exploration into whether or not quality process yields satisfying results. ${ }^{4}$ Was the mere use of a

$1 R$ v. Pauchay [2009] S.J. No. 2 (2009) 4 SKPC 1, [2009] 1 C.N.L.R. 317

2 Kevin Libin, "Sentencing circles for aboriginals: Good justice?" National Post, February 27, 2009.

3 Colby Cosh, "Colby Cosh on Christopher Pauchay: Squaring the Circle on Justice," National Post, November 7, 2008.

4 The benefits of using alternatives to formal adjudication have been described as quantitative-ADR is an efficient process that is cost effective and qualitativeparties feel more satisfied because the resolution is tailored to specific needs and interests, and parties are more involved in the process. See Carrie MenkelMeadow, "For and Against Settlement: Uses and Abuses of the Mandatory Settlement Conference," 33 UCLA L. Rev. 485, 487. 


\section{Sentencing Circles, Clashing Worldviews, and the Case of Christopher Pauchay}

sentencing circle sufficient to consider this case a success in trying to stem the conflict between Aboriginal offenders and the criminal justice system? Or, were cultural conflicts obscured by using a culturally appropriate process within a divergent legal system?5

The holistic approach of systems thinking is a good place to start unpacking these questions. For the purposes of this paper, the understanding of what constitutes a system (i.e., the criminal justice system) will be based on systems thinking. ${ }^{6}$ According to systems thinking, a system should be thought of as a whole. Its properties emerge from the myriad relationships between interdependent components that work together to achieve a purpose or goal. Systems theory is important in that it analyzes the behaviour of a system in its entirety. It advocates deep and meaningful evaluation of all a system's parts and interrelations, rather than solely considering individual units and how they function. How ADR processes act on, or are acted upon by the criminal justice system should be a part of the analysis of the efficacy of alternative methods.

Christopher Pauchay's case highlights the depth and complexity of cultural conflict, for the clash between the alternative sentencing circle process and the larger criminal justice system was informed by differing worldviews. It can be difficult to coherently capture the conflict that resides at this deep a level. As Michelle LeBaron has noted, such a conflict "takes us from the literal to the symbolic, from the obvious to the hidden ... there is much more under the surface than above it. Much more is sensed, felt, and intuited than can be named." This paper attempts to conduct a deeper investigation into the cultural starting points of underlying worldviews to reveal how separated the divergent approaches to crime really are.

Sentencing circles and other alternative programs, such as the Native Court in Grande Cache, Alberta or the Gladue Court in Toronto, were developed as a way to address the disproportionate

5 System in this essay is to be understood within a systems theory framework and therefore defined as the "integrated whole whose essential properties arise from the relationships between its parts." See Fritjof Capra, The Web of Life: A New Scientific Understanding of Living Systems (New York: Anchor Books, 1997), 27.

6 See Capra, The Web of Life, and Donella H. Meadows and Diana Wright, Thinking in Systems: A Primer (White River Junction: Chelsea Green, 2008). 7 Michelle LeBaron, Bridging Cultural Conflicts: A New Approach for a Changing World (San Francisco: Jossey-Bass, 2003), 30. 


\section{Tony Susan Goldbach}

incarceration rates and negative experiences of Aboriginal offenders. ${ }^{8}$

The first use of a sentencing circle as part of a criminal justice trial was in 1992, by Yukon Territorial Court Judge Barry Stuart in $R . v$. Moses. ${ }^{9}$ Stuart based the process on procedures used by First Nations communities in Mayo. In 1996, the Federal government began funding sentencing circles as part of an Aboriginal Justice Strategy. ${ }^{10}$ Also in 1996, amendments to the sentencing provisions of the Criminal Code legislated judges to consider all available alternatives to incarceration, "with particular attention to the circumstances of aboriginal offenders." ${ }^{11}$ Since then, sentencing circles have been used in Aboriginal communities to construct sentences related to various convictions such as aggravated assault, assault causing bodily harm, robbery with violence, sexual assault, criminal harassment, break and enter and arson.

At a sentencing circle, an inner circle is made of criminal justice participants, including the judge, prosecution, defence counsel, court reporter, the offender, the victim and their respective families. The

8 See Tim Quigley, "Are We Doing Anything about the Disproportionate Jailing of Aboriginal People?" 42 Criminal Law Quarterly (1999): 129; Task Force on the Criminal Justice System and Its Impact on the Indian and Metis People of Alberta (Canada), Report of the Task Force on the Criminal Justice System and its Impact on the Indian and Metis People of Alberta (Edmonton: The Task Force, 1991), 117; Leonard Mandamin, "Aboriginal Justice Systems: Relationships," in Aboriginal Peoples and the Justice System: Report of the National Round Table on Aboriginal Justice Issues (Ottawa: Royal Commission on Aboriginal Peoples, 1993), 286-287; Craig Proulx, Reclaiming Aboriginal Justice, Identity, and Community (Purich's Aboriginal Issues Series, Saskatoon: Purich Pub. 2003). The Native Court in Grande Cache was initiated by Provincial Court Judge M.H. Porter. The accused, once pleading guilty or being convicted, can ask to be sentenced in the Native Court. The Gladue Court in Toronto is based on the decision of the same name by the Supreme Court of Canada. Other programs include the Community Council Project in Toronto and smaller peacemaking initiatives, including the Tsuu T'ina Peacemaking Initiative where the Court is physically on reserve property and incorporates Aboriginal culture and resources.

9 R. v. Moses (1992), 71 C.C.C. (3d) 347 (Yukon Terr. Ct.)

10 Jonathan Kay, "The folly of native sentencing circles," National Post, January 20, 2009.

11 Section 718.2(e). The Supreme Court of Canada in R. v. Gladue [1999] 1 S.C.R. 688, 133 C.C.C. (3d) 385, 23 C.R. (5th) 197 specifically directed judges to take notice of "the types of sentencing procedures ... which may be appropriate in the circumstances for the offender because of his or her particular aboriginal heritage or connection." 


\section{Sentencing Circles, Clashing Worldviews, and the Case of Christopher Pauchay}

inner circle may also include probation officers, court workers, youth workers or police officers. Surrounding that circle is an outer circle of friends, relatives, and interested members of the community. The charges are read and brief opening remarks are made by the Crown and defense. Following that, the discussion is opened to other participants, with the procedure facilitated by either a judge or a respected member of the community. The procedure can often be lengthy and calls for high levels of commitment from the victim(s), accused and the community.

The sentencing circle for Christopher Pauchay was held on February 13, 2009 in Rose Valley near the Yellow Quill reserve. Twenty-three people were seated in an inner circle: Pauchay's parents, his wife (the mother of the victims), senior elders from Sturgeon Lake First Nation and the Yellow Quill First Nation, a mental health specialist, two surrogate victims, two facilitators, and court representatives. Another fifty to sixty people were in attendance but did not directly participate. A community elder from Sturgeon Lake recommended that Pauchay serve three traditional pipe carriers. This role is called an Oschapawis and responsibilities include setting up rocks for sweat lodges, filling and lighting pipes before ceremonies and assisting elders with other tasks. Fulfilling this role would have been for a lifetime and in that way Pauchay would have learned from the elders. The consensus at the circle was that Pauchay should serve his sentence in the community.

In his decision, which was released on March 6, 2009, Prov. Ct. J. Morgan affirmed that the sentencing circle gave "valuable insight into the view of Mr. Pauchay's community towards Mr. Pauchay and to the problems that community faces." ${ }^{2}$ Justice Morgan felt, however, that a proper balancing of the principles of sentencing required incarceration for a term of three years. Although Justice Morgan appreciated Pauchay's apology for bad behaviour and poor leadership, and noted the degree to which Pauchay was deeply affected by the incident, he still felt that Pauchay did not directly accept responsibility, or make a specific commitment to address his substance abuse. The judge wrote that the community's recommendations went beyond the scope of the sentencing circle and that he had no power to give effect to many of their requests, including, for example, the ordering of a lifetime

12 R. v. Pauchay [2009] S.J. No. 128 (2009) 35 SKPC 11. 
of service to the elders. In paragraph 69 of the judgement, Justice Morgan states: "Although I appreciate the input of the community of Yellow Quill, as expressed through the process of the Sentencing Circle, I cannot agree with the recommendations of that circle ... It will be up to Mr. Pauchay to decide, upon his release from prison, whether he wants to access the community support that is available to him at Yellow Quill First Nation." ${ }^{13}$

From a legal perspective, Justice Morgan did everything right. He properly considered a sentencing circle to be appropriate, and he properly applied precedent and codified principles in delivering his sentence. The outcome of the sentencing process must have been deeply unsatisfying to many of the participants, and should be troubling for advocates of alternative dispute resolution processes. The community spent five hours at the circle (and much more time in advance of that date) drafting and articulating an appropriate response to the crime. Why were the recommendations of the sentencing circle not sufficient in the eyes of the court? What do the outcomes in this case reveal about the possibility of using alternative processes within the criminal justice system?

\section{A Cultural Analysis of Conflict in the Criminal Justice System}

At the level of values or principles, the similarities between sentencing circles and restorative justice are considerable. Both, for instance, can be distinguished from the criminal justice system, which values denunciation, deterrence and removal of offenders from society, and the Department of the Solicitor General of Canada compared the starting point for a discussion of restorative justice in Canada to the roots of restorative justice in the cultures of Aboriginal peoples. ${ }^{14}$ In both arenas, crime is considered a violation of relationships, and

\footnotetext{
13 Ibid.

14 Robert Cormier, "Restorative Justice: Directions and Principles-Developments in Canada 2002-02" (Department of the Solicitor General Canada, 2003). See "Justice on Trial (Cawsey Report)," "Report of the Task Force on the Criminal Justice System and its Impact on the Indian and Metis People of Alberta," March 1991, and Jonathan Rudin, "Pushing Back - A Response To the Drive for the Standardization of Restorative Justice Programs in Canada," 6th International Conference on Restorative Justice, available at SFU Centre for Restorative Justice: http://www.sfu.ca/cfrj/fulltext/rudin.pdf.
} 


\section{Sentencing Circles, Clashing Worldviews, and the Case of Christopher Pauchay}

justice is understood as the righting of relationships, the promotion of reconciliation, and the restoration of harmony. In addition to recognizing the rehabilitative needs of offenders, both sentencing circles and restorative justice approaches consider the needs of victims. Generally, both seek to encourage moral growth, foster positive attitudes, empower individuals, families and communities to take responsibility for their actions, and constructively resolve differences. For example, the mental health specialist who participated in the sentencing circle for Christopher Pauchey recommended intervention strategies such as workshops to teach parenting and life skills, mentoring programs for youths, and a children's help phone line. These recommendations reflect the attempt to restore harmony to relationships by addressing the entire community's responsibility for the tragedy. Indeed, it was precisely because of the similar values and principles shared by sentencing circles and Restorative Justice that one of the ways that sentencing circles were promoted for usein the criminal justice system was by indicating their value within a more general Restorative Justice approach. ${ }^{15}$

Reports and scholarly works that only focus on the values informing sentencing circles miss the comprehensive content that exists at the deeper level of worldviews. How do worldviews differ from values? Mark Davidheiser argues that worldviews are "the

15 See, for instance, Pamela Boisvert, "Aboriginal Peoples and Restorative Justice: The Promise of Sentencing Circles" (Canadian Forum on Civil Justice, Dispute Resolution Awards in Law Studies, Department of Justice Canada, 2003), available at http://cfcj-fcjc.org/clearinghouse/drpapers/2003-dra/boisvert.pdf, and Territorial Judge (Whitehorse) H. Lilles, "Circle Sentencing: Part of the Restorative Justice Continuum," Plenary Speaker, "Dreaming of a New Reality," Third International Conference on Conferencing, Circles and other Restorative Practices, August 8-10, 2002, Minneapolis, Minnesota, available at International Institute for Restorative Practices: http://www.iirp.org/library/mn02/mn02_lilles. html. Recent appeals to restorative justice began in the 1970s, in order to address the arrests of two young offenders in Kitchener, Ontario. See Law Commission of Canada, From Restorative Justice to Transformative Justice: Discussion Paper (Ottawa: Law Commission of Canada, 1999). Since that time, restorative justice programs have begun to operate in North America, Europe, Australia and New Zealand. Two common restorative justice initiatives are victim-offender reconciliation (victim and offender are brought together with a trained facilitator to discuss the conflict and identify strategies to repair the harm done) and family group conferences (more participants are present, including family members and professionals). 
interpretive filters inherent in cognition (how we perceive and understand life and particular events)." ${ }^{16}$ David Thomas uses the metaphor of an iceberg to describe successive levels of culture, and therefore helps clarify what makes worldviews unique. If culture is an iceberg, above the surface of the water are visible cultural artefacts like architecture or music. Just below the surface lay consciously held values or principles. It is extremely deep below the surface where underlying assumptions and worldviews - the source of values and actions-are hidden. ${ }^{17}$ It is worthwhile to keep Thomas's metaphor in mind when approaching the topic of cross-cultural dispute resolution. Imagine trying to adopt another culture's dispute resolution process as an alternative to the conventional process just because the values and principles of the alternative process are appealing. This would merely amount to attempting to move the area of one cultural iceberg that is just below the surface to the same area of another cultural iceberg. The deeper and much larger bases of the cultural icebergs present a problem. Not only are they harder to move, even if both cultural icebergs remain intact and live side by side, the span and shape of their bases will ensure that the areas of values and principles living just below the surface will be far away from each other, and separated by an ocean of difference. This is the difficulty of trying to incorporate a process modeled on Aboriginal healing circles into the Euro-Western criminal justice system. At a superficial level, there may appear to be overlapping values, but these shared values have very different and often obscured foundations. In the case of Christopher Pauchey, the outcome of the sentencing process highlighted how large and separated cultural icebergs really can be.

Culture is the "set of invisible rules" which "shapes our ideas of what is important, influences our attitudes and values and animates our behaviours." ${ }^{18}$ It is historically derived, selected and produced, and it informs how issues are understood. Culture is activated and constructed through participation in social institutions, and dispute resolution procedures are particularly critical to the ongoing job of

16 Mark Davidheiser, "Race, Worldviews, and Conflict Mediation: Black and white styles of Conflict Revisited," Peace \& Change 33 (2008): 67.

17 David C. Thomas, Cross-cultural Management: Essential Concepts, 2nd ed. (Los Angeles: Sage Publications, 2008), 30.

18 Michelle LeBaron, Bridging Cultural Conflicts: A New Approach for a Changing World, 1st ed. (San Francisco: Jossey-Bass, 2003), 17. 


\section{Sentencing Circles, Clashing Worldviews, and the Case of Christopher Pauchay}

transmitting and maintaining culture. In this way, legal institutions are one of the main methods of communicating social values and understandings. According to Alan Hunt, "Law is the most visible, formalised element in the processes of social regulation" because legal institutions give an authoritative voice to "a system of rules and sanctions that stipulate how people should act." ${ }^{\prime 19}$

Legal institutions are able to access what Max Weber referred to as the "legal rational" authority by appealing to a formal rational process. ${ }^{20}$ Legal rational authority in the criminal justice system reflects a kind of power: the power to administer sanctions based on the decision maker's legal authority to direct punishment and sentencing. Authority is only one form of power, but in Weber's analysis, it is the most stable and enduring form. ${ }^{21}$ It is important to note that participation in the criminal justice system also reconstructs authority. A system may have the authority to process offenders, sentence them to incarceration or put limits on their freedom, but it is also through the ongoing participation of legal actors that the system becomes legitimated. Ongoing participation can thus add an element of traditional authority to legal rational authority. ${ }^{22}$

In order to facilitate discussion about worldviews, Michelle LeBaron and Venashri Pillay delineate six cultural starting points that characterize different cultures. ${ }^{23}$ They differentiate between high context communication in which meaning is taken from behaviour and nonverbal communication, and low context communication which is more direct. Cultures based on individualism value individuality and independence, whereas communitarian cultures seek group harmony, cohesion and understand people to be interdependent. Universal cultures broadly apply rules, laws, or generalizations with an emphasis on standardization, whereas particularism yields circumstance-

19 Alan Hunt, "The Problematisation of Law in Classical Social Theory," in An introduction to Law and Social Theory, eds. Reza Banakar and Max Travers (Oxford: Hart, 2002), 26.

20 See Anthony Kronman, Max Weber (Stanford: Stanford University Press, 1993).

21 Ibid., 39.

22 Ibid., 44.

23 Michelle LeBaron and V. Pillay, Conflict Across Cultures: A Unique Experience of Bridging Differences (Boston: Intercultural Press, 2006). 
specific meanings with "custom-fit behaviours and living." ${ }^{4}$ Specific cultures value efficiency, well defined tasks and measurable outcomes; diffuse cultures value attention to process because of the emphasis on "the big picture." ${ }^{25}$ High and low power distance relate to "the extent to which power differences are accepted and sanctioned in a society" or the "degree to which members of a collective expect power to be distributed equally."26 Finally, in cultures that consider time sequential, time is rigid and exact. There is a separation of past, present and future into distinct periods, with a major focus on the present and short term. In synchronous-time cultures, time is "cyclical, episodic, and circular." It may be seen to stretch "far beyond the human ego or lifetime." ${ }^{27}$ Below is an initial description of the worldviews that inform the Euro-Canadian criminal justice system and those that inform the sentencing circle process. By comparing the starting points of these differing approaches to criminal justice, the conflicts existing deep below the surface can be revealed.

The preamble to the Canadian Charter of Rights and Freedoms states that Canada is "founded upon principles that recognize the supremacy of God and the rule of law." In this one statement, universalism and high power distance are evidenced as starting points of the Euro-Canadian worldview. James Frideres explains that the Western monotheistic religion, with God on top of a cascading network of angels, men and other forms of life, points to a hierarchical worldview. ${ }^{28}$ Hierarchy is also evident in bureaucratic structure and in concepts of sovereignty, which can apply to authority vested in a monarch or to authority in the form of a constitution or government above the citizenry. ${ }^{29}$ Cultures that are bureaucratic are based on order,

24 Ibid., 38.

25 Ibid., 41.

26 Thomas, Cross-cultural Management, 50, 61.

27 LeBaron and Pillay, Conflict Across Cultures, 43.

28 James Frideres, Native People in Canada: Contemporary Conflicts, 4th ed. (Scarborough: Prentice Hall Canada, 1993).

29 Oscar G. Chase, Law, Culture, and Ritual: Disputing Systems in Cross-cultural Context (New York: New York University Press, 2005). Chase writes that Western-based cultures are in constant struggle with the hierarchical element of their culture in contradistinction to the distaste for centralization of power. For example, on the one hand, the government is expected to provide protection from harm and injustice, but at the same time the population is mistrustful of concentration of power, creating tension at the governmental level. 


\section{Sentencing Circles, Clashing Worldviews, and the Case of Christopher Pauchay}

specialist knowledge and an orientation to product over process. They are therefore specific, rather than diffuse.

The Euro-Canadian view of time is sequential. Time is generally understood as linear and singular, made up of the past, present and future. It can be split up into similar units (a minute, a day) that are the same length of time. ${ }^{30}$ This linear view of time leads to singularity, which is consistent with singular identities (e.g. individualism) and a hierarchical order. Universalism informs an individualistic worldview. Oscar Chase writes that rights-based discourse contributes to the concept of the self as an individual. Similarly, John Stuart Mill's writings on liberty and the principle of non-interference describe universal concepts that support an individualized society. It is the individual who has freedom from the state, but also, implicitly, from the community. The individual has a right to act without interference from others, and so society is reduced to discrete units of individuals. The adversarial legal proceeding, which "unfolds as an engagement of two adversaries before a relatively passive decision maker" reflects this individualist worldview and the universal concept of noninterference. ${ }^{31}$

Considering the ways in which many Aboriginal peoples conceive of time is helpful in attempting to unpack the relationship between Aboriginal worldviews the sentencing circle process. Time, in this cultural context, is often understood to be synchronous and cyclical. Since it consists of cosmological cycles and patterns, day to day time is not an important referent..$^{32}$ The circle is a key symbol: it has no beginning or ending, but goes round and round, like the cyclical patterns of the cosmos. The circle also symbolizes wholeness, equality and connectedness. This points to worldviews that are more comfortable with low power distance and communitarianism. ${ }^{33} \mathrm{~A}$ holistic worldview sees all things as connected, and the circle becomes broken when a wrong is committed. In order to restore equilibrium, particular work needs to be done in order to reconcile offenders with their own consciences and with the families they have wronged. ${ }^{34}$

30 Report of the Task Force on the Criminal Justice System, 9-1.

31 Chase, Law, Culture and Ritual, 54.

32 Report of the Task Force on the Criminal Justice System.

33 James Dumont, "Justice and Aboriginal People," in Report of the National Round Table on Aboriginal Justice Issues, 57.

34 Ibid., 69. 
Justice is therefore the particular experience in the relationship between the victim, the offender and the community. In cultures where time is cyclical and repetitive patterns are observed, the focus is usually on process (rather than goal-orientation). For example, Rupert Ross notes that the important aspect of "consensus decision-making" is not that everyone agrees, but that the process is communal. ${ }^{35}$ Low power distance and diffuse starting points can contribute to high context communication. In describing Aboriginal communication, Ross writes that giving advice is generally considered to be improper and that opinions are relayed through subtle recitation and repetition of important facts. James Dumont shares an example told by a Longhouse elder, which highlights a diffuse approach to conflict resolution. Several adolescent boys of the Longhouse tradition had admitted to vandalism. They explained that they did it because they had nothing else to do. In response, the elders asked them to think about ways their time could have been put to better use. They were then asked to think about what they would do the other six nights in the week, and then the weeks ahead, and so on. Through this broad and cyclical process, a plan for behaviour modification developed.

Table 1 compares the starting points that inform the principles and values of the sentencing circle process versus the criminal justice system. Comparing the starting points side by side reveals the distance between the underlying worldviews.

Reflecting on starting points in this way helps illustrate the conflict between the conventional criminal justice system and the sentencing circle process. In the Pauchay case, there were conflicts between the system's demand for specific answers and the diffuse nature of the circle process. Justice Morgan felt that he could not rely on the general or unspecific information that was relayed. For example, when a nonAboriginal facilitator asked Pauchay to explain what happened the day his daughters died, Pauchay recounted how he sat up all night with one of his daughters when she was in hospital with a fever and how he was present when his youngest daughter took her first steps. ${ }^{36}$ Sharing his strong emotional connection to the children he lost was an integral

35 Rupert Ross, Dancing with a Ghost: Exploring Indian Reality (Markham: Octopus Books, 1992).

36 Betty Ann Adam, “I feel so bad': Pauchay; Father of Dead Children Testifies at Sentencing Circle," The StarPhoenix, February 14, 2009. 
part of his account of the tragic night. The non-Aboriginal facilitator, however, was likely looking for Pauchay to recount the actions he took and the choices he made from a chronological perspective. Pauchay's answer must have seemed obscure and indirect.

Table 1. Process and System Conflict Based on Worldviews

\begin{tabular}{|l|l|l|}
\hline Starting Points for: & $\begin{array}{l}\text { Western-Based Justice } \\
\text { (Sentencing Hearings) } \\
\text { Symbol: The Gavel }\end{array}$ & $\begin{array}{l}\text { Aboriginal-Based Justice } \\
\text { (Sentencing Circle*) } \\
\text { Symbol: The Circle }\end{array}$ \\
\hline Justice & $\begin{array}{l}\text { Universal principles } \\
\text { Sequential view of time }\end{array}$ & $\begin{array}{l}\text { Particular experience } \\
\text { Synchronistic view of time }\end{array}$ \\
\hline View of Crime & $\begin{array}{l}\text { Universal and high power } \\
\text { differential starting points }\end{array}$ & $\begin{array}{l}\text { Particular and low power } \\
\text { differential starting points }\end{array}$ \\
\hline Guilt or Responsibility & $\begin{array}{l}\text { Individualism } \\
\text { Least interference }\end{array}$ & $\begin{array}{l}\text { Communitarianism and } \\
\text { obligations }\end{array}$ \\
\hline $\begin{array}{l}\text { Participants, } \\
\text { Level of Involvement }\end{array}$ & $\begin{array}{l}\text { Individuals, atomistic } \\
\text { Representational, speaks to } \\
\text { comfort with high power } \\
\text { differential }\end{array}$ & $\begin{array}{l}\text { Community } \\
\text { Direct involvement speaks to } \\
\text { low power differential }\end{array}$ \\
\hline Procedure & $\begin{array}{l}\text { Universal principles } \\
\text { Low context }\end{array}$ & $\begin{array}{l}\text { Particular } \\
\text { High context }\end{array}$ \\
\hline Relevant Facts & $\begin{array}{l}\text { Specific worldview } \\
\text { Sequential view of time }\end{array}$ & $\begin{array}{l}\text { Diffuse worldview } \\
\text { Synchronistic view of time }\end{array}$ \\
\hline $\begin{array}{l}\text { Appropriate Content } \\
\text { of Decision }\end{array}$ & $\begin{array}{l}\text { Universal sentencing } \\
\text { principles } \\
\text { Sequential view of time }\end{array}$ & $\begin{array}{l}\text { Particular orientation } \\
\text { Synchronistic view of time }\end{array}$ \\
\hline Decision Maker & High power differential & Low power differential \\
\hline
\end{tabular}

* Sentencing circle based on traditional healing circles.

The Pauchay case also reveals a conflict between universal and particular worldviews. The Yellow Quill First Nation Justice Committee requested closing the circle to the media to allow for a deeper healing process. Their request was denied due to the judge's commitment to the universal values of transparency and accountability which demand open procedures and public access to the courts. There was conflict between sequential and synchronistic orientations to time: 


\section{Tony Susan Goldbach}

the community recommended that Pauchay serve the elders for a lifetime, whereas the judge had no power to order such service.

\section{The Risk of Re-colonialization}

At a National Conference on Native Peoples and the Criminal Justice System held in Edmonton in 1975, recommendations were made to develop programs that deal with Aboriginal conflicts with the law, and to involve the Aboriginal community in the design and delivery of justice services. Encouraging an Aboriginal justice movement was a way of restoring respect and power to traditional justice measures. It was characterised as an effort towards de-colonialization, by reasserting Aboriginal control in the justice system. ${ }^{37}$ Since the 1975 conference, however, there has not been a significant decrease in the numbers of altercations between Aboriginal peoples and the law. In fact, in most jurisdictions, rates of arrest, conviction and incarceration are higher than they were prior to $1975 .^{38}$

Some advocates for reform argue that any parallel or separate Aboriginal justice system should have substantial linkages to the existing system..$^{39}$ The sentencing circle for Christopher Pauchay, however, demonstrates that using a parallel process which maintains strong links to the existing criminal justice system can have very mixed results. It is interesting to note that unofficial numbers released by the ministry of justice in Saskatchewan show that the number of sentencing circles used within the criminal justice system has gone down from a high of thirty-nine in 1997 to one in 2007 and five in $2008 .^{40}$ While the minister did not provide reasons for the decline, one might speculate that what might have seemed like a great idea to ADR advocates in 1997 would have seemed less so after ten years of sentencing circles' recommendations being disregarded. ${ }^{41}$

37 Mandamin, "Aboriginal Justice Systems: Relationships."

38 J.C. Yerbury \& C.T. Griffiths, "Minorities, Crime and the Law" in Diversity and Justice in Canada, eds. J. A. Winterdyk and D. E. King (Toronto: Canadian Scholars' Press, 1999).

39 J. Giokas "Accommodating the Concerns of Aboriginal People within the Existing Justice System," in Diversity and Justice in Canada, ibid.

40 Lori Coolican, "Pauchay Wants to Go For Alcohol Rehab: Lawyer," Canwest News Service, January 16, 2009, available at http://www.nationalpost.com.

41 Examples of cases where sentencing circle recommendations were not followed include R. v. Langan [2010] S.J. No. 43 and R. v. Elliot [2006] A.J. No. 


\section{Sentencing Circles, Clashing Worldviews, and the Case of Christopher Pauchay}

Richard Abel and Steven Spitzer have applied Foucault's theory of discipline as a "milder gentler form of control" to ADR. ${ }^{42}$ They argue that $\mathrm{ADR}$ is part of the movement from punishment to discipline; part of a "thinning of the mesh and widening of the net." ${ }^{43}$ Because $\mathrm{ADR}$ is softer and gentler, it can access and have control over more behaviour. This differentiation between discipline and punishment is less clear when the ADR process is annexed to the criminal justice system. Even if Pauchay participated in a seemingly softer process, he was still punished with a term of incarceration. Thus, it was not just that participating in the process reconstructed the system's authority. Rather, participating in the process still yielded punishment type results. It is not enough to appeal to alternative processes just for the sake of process. Without considering the outcomes or consequences for the individual offender and the community, ADR itself is at risk of becoming a tool of further colonization. The incorporation of alternative processes that are reflective of traditional Aboriginal methods was meant to restore respect and authority. The outcome in the Pauchay case, however, may have had the exact opposite effect. The Judge thanked the community for their participation, but then sentenced Christopher Pauchay as if the recommendations had never been made. With their work and voices disregarded, the members of the community retreated from their temporary role in the justice system, and Pauchay moved on to jail.

The history of Aboriginal and non-Aboriginal contact consists of an intentional and long-term path towards replacing indigenous selfdeterminism with a dependant and subordinate status. That history includes the reserve system, residential schools and other ways that Aboriginal political, economic, kinship and religious systems have been (and continue to be) ignored and absorbed. ${ }^{44}$ The Indian Act

1686; 2006 ABPC 372. Many of the sentences in cases where sentencing circle recommendations were followed were overturned on appeal; see generally Luke McNamara, "Appellate Court Scrutiny of Circle Sentencing" (1999-2000) 27 Man. L.J. 209.

42 Richard L. Abel, "The Contradictions of Informal Justice" in The Politics of Informal Justice: Studies on Law and Social Control, ed. Richard L. Abel (Toronto: Academic Press, 1982) and Gary Wickham, "Foucault and Law" in An Introduction to Law and Social Theory.

43 Steven Sptizer, "Dialectics of Formal and Informal Justice," in The Politics of Informal Justice.

44 Frideres, Native Peoples in Canada: Contemporary Conflicts, CBC News, 


\section{Tony Susan Goldbach}

is probably one of the most contentious symbols of colonialism, and it too played a part in Mr. Pauchay's case. Chief Robert Whitehead of the Yellow Quill Tribal Council reported to CBC that, prior to the Pauchay tragedy, reserve officials passed a bylaw to declare the reserve dry because of the struggles with the effects of alcohol abuse and suicide. Documents needed to be mailed to Indian and Northern Affairs Canada (INAC) within four days of enactment, but, according to Chief Whitehead, this was not done and the reserve received notice from INAC that the bylaw was of no effect. An Aboriginal Justice movement was seen as a way of responding to, and changing the course of history. Sentencing circles and other efforts to promote Aboriginal approaches to conflict were meant to address the negative treatment that Aboriginal people experience in the criminal justice system. If sentencing circle recommendations are disregarded-especially following a lengthy and court mandated process-then Aboriginal status and views are still suffering from subordination. The sentencing circle process is co-opted and absorbed into the overarching system, but not for the lasting benefit of Aboriginal peoples. As the Pauchay case suggests, the benefit for Aboriginal peoples is largely superficial.

\section{Bridging the Conflict-Self-Awareness}

Clifford Geertz describes people as being suspended in self-spun "webs of significance." ${ }^{45}$ Social institutions are an especially essential and enduring part of this web, and through general participation in social institutions, cultural webs are continually spun. Socially constructed meanings are both inserted into, and help build institutions and in that way, they become general and accessible. There has been much introspection into, and reflection on, Aboriginal culture and experiences within the criminal justice system. ${ }^{46}$ There needs to be

January 31, 2008.

45 Clifford Geertz, The Interpretation of Cultures; Selected Essays (New York: Basic Books, 1973).

46 Robert Silverman and Marianne O Nielsen, eds., Aboriginal Peoples and Canadian Criminal Justice (Toronto: Butterworths, 1992); Winterdyk and King, eds., Diversity and Justice in Canada (Toronto: Canadian Scholars' Press, 1999); Frideres, Native Peoples in Canada: Contemporary Conflicts; Ross Gordon Green, Justice in Aboriginal Communities: Sentencing Alternatives (Purich's Aboriginal Issues Series, Saskatoon: Purich, 1998); Matthias R. J. Leonardy and University of Saskatchewan Native Law Centre, First Nations Criminal Jurisdiction in 


\section{Sentencing Circles, Clashing Worldviews, and the Case of Christopher Pauchay}

more investigation into the cultural influences of the Euro-Western criminal justice system, from the perspective that institutions are socially and culturally constructed. Those who participate in the criminal justice system should reflect on how views and principles have been shaped, and be open to acknowledging that there are deep assumptions and beliefs which inform habitual ways of doing things. Judge Morgan did not reflect on how his assumptions of offender behaviour or sentencing proceedings were informing his expectations. Rather, his decision was informed by his perception that Pauchay lacked a sense of responsibility regarding his alcoholism.

In his classical study Orientalism, Edward Said detailed how the West orientalised the East through a century of investigation and description. ${ }^{47}$ In a similar way, Canadian criminal justice literature risks aboriginalizing Native Canadian experiences. Reports by federal and provincial governments on the experience of Aboriginals in the Canadian criminal justice system are strikingly similar to the cultural investigation of "the Other" criticized by Said. ${ }^{48}$ Indeed, Craig Proulx points out that the "Indian" is a social construct, initially defined by colonizers, academics and the media, and currently "sustained by the dominant society though the system of stereotypes." ${ }^{49}$ To avoid aboriginalizing Native Canadian experiences, those who work in, and think about, the criminal justice system should follow Tatsushi Aria's recommendations for developing cultural fluency. In order to become culturally fluent, one must develop self-awareness through articulation of why we care about what we care about and by probing assumptions about behaviour and proper justice that have become

Canada: The Aboriginal Right to Peacemaking Under Public International and Canadian Constitutional Law (Saskatoon: Native Law Centre, University of Saskatchewan, 1998); Proulx, Reclaiming Aboriginal Justice; Rupert Ross, Dancing with a Ghost: Exploring Indian Reality (Markham: Octopus Books, 1992); Rupert Ross, Returning to the Teachings: Exploring Aboriginal Justice (Toronto: Penguin Canada, 2006).

47 Edward Said, Orientalism, 1st ed. (New York: Vintage Books, 1979).

48 See National Round Table on Aboriginal Justice Issues and Canada Royal Commission on Aboriginal Peoples, Aboriginal Peoples and the Justice System; Task Force on the Criminal Justice System and Its Impact on the Indian and Metis People of Alberta (Canada), Report of the Task Force; Law Commission of Canada and Dennis Cooley, From Restorative Justice to Transformative Justice: Discussion Paper (Ottawa: Law Commission of Canada, 1999).

49 Proulx, Reclaiming Aboriginal Justice, 129 
static or stabilized in social institutions. ${ }^{50}$ By paying attention "to our inner experiences-feelings, thoughts, imaginings, triumphs, and disappointments," we are better suited to understanding ourselves, our habitual responses, and our deep and influential social assumptions. ${ }^{51}$ Only from that place of understanding can we begin to consider fruitful occasions for alternative methods and approaches. Developing cultural fluency is important not just in approaching cultural conflict between individuals. On a broader level, the same efforts should be undertaken when designing, adapting or participating in ADR processes that may conflict with the culture of the overarching legal system.

The critical writings of Weber and Foucault, and the descriptive social jurisprudence of Brian Tamanaha or Oscar Chase, demonstrate efforts at self-awareness by examining modern European legal systems through the lens of cultural history. For example, Weber highlights the connection between Western monotheistic religion and the prominence of contract in legal and political theory. The contract between God and Abraham was the foundation on which Western monotheistic religion was built. It is also reflected in the social contract between the ruler and the ruled and it explains the ease with which English society shifted to a contract-based economy in the early capitalist period. As another example of self-awareness, Foucault's writing in Discipline and Punish (1977) provides an alternative explanation for the adherence to open courts. The public nature of proceedings, rather than reflecting a desire for open and democratic legal structures, instead can be seen to derive from a historical legacy of participation in public executions. Universalism, which is a foundational aspect of Euro-Western based cultures, is especially difficult to unpack, for it can easily and inherently defy particular self-description. Rather than solely historicizing Western legal theories as a transition from "primitive" to complex legal systems, we need to become more aware of their prescriptive elements. ${ }^{52}$ More work can and should be done to unpack some of the paradoxes in Euro-Canadian legal culture, such as that between the hierarchical

50 Tatsushi Aria, "A Journey toward Cultural Fluency" in Conflict Across Cultures, 61.

51 Ibid., 61.

52 Jeanne L. Schroeder, “Totem, Taboo and the Concept of Law: Myth in Hart and Freud," Jurisprudence Review 1 (2009): 139. 
legal/political structure and the coordinate ideals that are inherent in the values of populism, individualism and egalitarianism. Having a better sense of the complexity of any system may encourage the acceptance of difficulties and complexities in other systems. Through awareness of the complexities on either side, perhaps a more balanced bridge can be built between different cultural icebergs.

Michelle LeBaron writes that "bridging conflict necessarily means cultivating comfort with change and ambiguity." ${ }^{53}$ The ambiguity of legal pluralism is certainly one way to bridge cultural conflicts that are embedded in the criminal justice system. Before one can advocate for legal pluralism, or make room for alternative processes, a "selfreflective" system must exist. It is important to think about and develop alternative ways to dealing with sentencing and resolving disputes, and looking to different cultures and methods can provide a rich basis for designing those alternatives. There must be reflection, however, on the overarching system and how it responds in ways that are characteristic of its own rules, and the deep and abiding worldview that creates them. What has been considered here is the alienation or structural embedding of conflict in the struggle between an alternative sentencing circle process and the criminal justice system. The use of an alternative process in the Pauchay case may have temporarily obscured the cultural conflicts at play, but it did not resolve, or successfully address them. In the end, the alternative approach was ineffectual. The cultures of both the alternative process and the criminal justice system need to be thoroughly and consciously considered in order for sentencing circles to maintain an alternative and relevant status.

\section{Bibliography}

Adam, B. "I feel so bad': Pauchay; Father of Dead Children Testifies at Sentencing Circle." The Star Phoenix. February 14, 2009.

53 Michelle LeBaron, Bridging Cultural Conflicts: A New Approach for a Changing World, 1st ed. (San Francisco: Jossey-Bass, 2003). 
Bakht, N. "Problem Solving Courts as Agents of Change." Criminal Law Quarterly 50, 224 (2005).

Banakar, Reza and Max Travers. An Introduction to Law and Social Theory. Oxford: Hart, 2002.

Boisvert, P. (2003). "Aboriginal Peoples and Restorative Justice:

The Promise of Sentencing Circles." University of Ottawa

(Common Law). Available at Clearing House: http://cfcj-fcjc.org/ clearinghouse/drpapers/2003-dra/boisvert.pdf.

Capra, Fritjof. The Web of Life: A New Scientific Understanding of Living Systems. New York: Anchor Books, 1997.

CBC News. "Killer of Mi'kmaq Activist Bernard Sentenced to 15 Years." January 23, 2009.

CBC News. "Killer of Native Activist Drops Request for Sentencing Circle." October 9, 2008.

CBC News. “You Can't Buy My Mother's Life Back': Daughter of Nora Bernard Says Sentencing Circle Not Appropriate for Killer." September 24, 2008.

Chase, Oscar G. Law, Culture, and Ritual: Disputing Systems in Cross-Cultural Context. New York: New York University Press, 2005.

Cormier, R.B. (Department of the Solicitor General Canada). "Restorative Justice: Directions and Principles-Developments in Canada 2002-02." http://ww2.ps-sp.gc.ca/publications/ corrections/200202_e.asp.

Cosh, C. "Colby Cosh on Christopher Pauchay: Squaring the Circle on Justice." National Post. November 7, 2008.

Davidheiser, Mark. "Race, Worldviews and Conflict Mediation: Black and White Styles of Conflict Revisited." Peace \& Change 33, 1 (January 2008). 
Sentencing Circles, Clashing Worldviews, and the Case of Christopher Pauchay

Foucault, Michel. Discipline and Punish: The Birth of the Prison. London: A. Lane, 1977.

Frideres, James, James Native people in Canada Frideres, and James Canada's Indians Frideres. Native Peoples in Canada: Contemporary Conflicts. 4th ed. Scarborough: Prentice Hall Canada, 1993.

Galaway, Burt and Joe Hudson. Restorative Justice: International Perspectives. Monsey: Criminal Justice Press, 1996.

Galloway, G. "Man pleads guilty in daughters' freezing deaths." Globe and Mail. November 3, 2008.

Geertz, Clifford. The Interpretation of Cultures; Selected Essays. New York: Basic Books, 1973.

Gladue (Aboriginal Persons) Court, Ontario Court of Justice-Old City Hall. Fact Sheet, available at: http://www.aboriginallegal.ca/ docs/apc_factsheet.htm

Green, Ross Gordon. Justice in Aboriginal Communities: Sentencing Alternatives. Purich's Aboriginal Issues Series. Saskatoon: Purich, 1998.

Kay, J. "The folly of native sentencing circles." National Post. January 20, 2009.

Kronman, Anthony T. Max Weber. Jurists-Profiles in Legal Theory. Stanford: Stanford University Press, 1983.

Kwochka, D. "Aboriginal Injustice: Making Room for a Restorative Paradigm.” Sask. L. Rev. 60, 153 (1996).

Law Commission of Canada. From Restorative Justice to Transformative Justice: Discussion Paper. Ottawa: Law Commission of Canada, 1999.

LeBaron, Michelle. Bridging Cultural Conflicts: A New Approach for a 
Changing World. 1st ed. San Francisco: Jossey-Bass, 2003.

LeBaron, Michelle and Venashri Pillay. Conflict Across Cultures: A Unique Experience of Bridging Differences. Boston: Intercultural Press, 2006.

Libin, K. "Sentencing Circles for Aboriginals: Good justice?" National Post. February, 27, 2009.

Lilles, H., Territorial Judge Whitehorse (2002). "Circle Sentencing: Part of the Restorative Justice Continuum." Third International Conference on Conferencing, Circles and other Restorative Practices, August 8-10, 2002, Minneapolis, Minnesota. Available at http://www.iirp.org/library/mn02/mn02_lilles.html

Linker, M. "Sentencing Circles and the Dilemma of Difference." Criminal Law Quarterly 42, 116 (1999).

Menkel Meadow, Carrie "Pursuing Settlement in an Adversary Culture: A Tale of Innovation Co-Opted Or 'the Law of ADR"' Florida State University Law Review 19, no. 1 (1991).

National Round Table on Aboriginal Justice Issues (1992 : Ottawa, Ont.) and Canada. Royal Commission on Aboriginal Peoples. Aboriginal Peoples and the Justice System: Report of the National Round Table on Aboriginal Justice Issues. Ottawa: Royal Commission on Aboriginal Peoples, 1993.

Proulx, Craig. Reclaiming Aboriginal Justice, Identity, and Community. Purich's Aboriginal Issues Series. Saskatoon: Purich Pub., 2003.

Quigley, T. "Are We Doing Anything about the Disproportionate Jailing of Aboriginal People?” Criminal Law Quarterly 42, 129 (1999).

Roberts, J.V. Roberts and LaPrairie, C. "Sentencing Circles: Some Unanswered Questions.” Criminal Law Quarterly 39, 69 (1997). 
Sentencing Circles, Clashing Worldviews, and the Case of Christopher Pauchay

Ross, Rupert. Dancing with a Ghost: Exploring Indian Reality. Markham: Octopus Books, 1992.

Ross, Rupert. Returning to the Teachings: Exploring Aboriginal Justice. Toronto: Penguin Canada, 2006.

Rudin, Jonathan. "Pushing Back-A Response to the Drive for the Standardization of Restorative Justice Programs in Canada." 6th International Conference on Restorative Justice (2003). Available at http://www.sfu.ca/cfrj/fulltext/rudin.pdf.

The Sacred Tree. Lethbridge: Four Worlds Development Project, 1984.

Said, Edward W. Orientalism. New York: Vintage Books, 1979.

Sawatsky, Jarem. "Restorative Values: Where Means and Ends Converge." 6th International Conference on Restorative Justice. (2003). Available at http://www.sfu.ca/cfrj/fulltext/sawatsky.pdf

SFU Centre for Restorative Justice. (2001). "Restorative Justice: A Summary." Available at SFU Centre for Restorative Justice: http://www.sfu.ca/cfrj/fulltext/summary.pdf

Silverman, Robert and Marianne O Nielsen, eds. Aboriginal Peoples and Canadian Criminal Justice. Toronto: Butterworths, 1992.

Tamanaha, Brian Z. A General Jurisprudence of Law and Society. Oxford Socio-Legal Studies. Oxford: Oxford University Press, 2001.

Task Force on the Criminal Justice System and Its Impact on the Indian and Metis People of Alberta (Canada). Report of the Task Force on the Criminal Justice System and its Impact on the Indian and Metis People of Alberta. Edmonton: The Task Force, 1991.

Thomas, David C., and International Management. Cross-Cultural Management: Essential Concepts. 2nd ed. Los Angeles: Sage Publications, 2008. 


\section{Tony Susan Goldbach}

Winterdyk, J. A. and D. E. King. Diversity and Justice in Canada. Toronto: Canadian Scholars' Press, 1999.

Wood, J. "Justice Minister Clarifies Remark on Sentencing Circle." Saskatchewan News Network. 